\title{
Customer behaviour doing online shopping: Latvia's case
}

\author{
Lienīte Litavniece, Daina Znotina \\ Rezekne Academy of Technologies
}

\begin{abstract}
E-commerce is an important branch of economics, and it is the fastest growing retail market looking forward to reach more than 250 billion EUR in 2017. Sucessfull online business has impact on customer behaviour. The aim of the article is to study customer behaviour doing online shopping. The article contains analyses of theoretical approaches to consumer behaviour and results of the customer survey which was carried out to find out the Latvia's customer behaviour doing online shopping.
\end{abstract}

Keywords: customer behaviour, e-commerce, logistic.

\section{INTRODUCTION}

From the point of view of marketing, consumer behavior is the process of product choice, purchase, and consumption in order to meet consumer's wishes and needs [1]. There is a difference between the concepts of cosumer behaviour and connsumer action. The authors consider that the consumer behaviour is the individual's external manifestation, conduct, and attitude that are usually defined by vital needs and environmental conditions, while consumer action is an activity and its result which is socially significant and/or envisage independent choice and decision-making.

It is not simple to predict customer behavior, as it is influenced by many factors, for example, a customer says one thing on his/her preferences and needs, but acts quite the opposite in the trading venue. Age, income, and level of education, mobility, tastes etc. differentiate customers from each other. Marketing decision-making is no longer dependent solely on direct contacts with customers due to the increased number of trading enterprises and the emergence of specialized markets.

Appearance of the Internet at the end of the last century has introduced major changes in the business processes. Fast development of equipment and tehnologies, the foreign - political interests of countries, economic globalization, and many other external circumstances stimulate the changes in marketing and management [2]. Relevant changes were promoted in customers as well. Online shopping is a convenience that suits the busy lifestyle of today's consumers. Online brands that provide a positive and personalized online experience will win the loyalty of online shoppers [3].

It is very topical for entrepreneurs to study customer behavior during online shopping in order to ensure that supply meets demand. Scientists and practitioners increasingly research and explore customers behavior in the market (i.e., [4], [5] [6], [7], [8], [13].
The aim of the study: to research customer behaviour doing online shopping: Latvia's case.

The tasks set to achieve the aim:

- Explore the theoretical aspects of customer behavior;

- Analyze the survey data on the Latvian customers behaviour during online shopping;

- Draw appropriate conclusions, based on the results of the study.

\section{MATERIALS AND METHODS}

Scientific (article) and practical (law) information was used in the research.

A set of general scientific methods (monographic, logical constructive, graphic) and sociological research method (survey) were used to carry out the research.

The article has been prepared within the framework of the international research "Importance of customer preferences doing online shopping" that was carried out by Rezekne Academy of Technologies (Latvia), Kaunas University of Applied Sciences (Lithuania) and Bialystok University of Technology (Poland). A survey was conducted in all three countries during the period from September to December, 2016 with aim to study the customer behaviour during online shopping. In total, 1713 valid questionnaires (617 - in Poland, 558 - in Latvia and 538 - in Lithuania) were collected. The questionnaire consisted of 20 questions that could be relatively divided into several groups: characteristics of respondents (age, gender, education, etc.), search, choice, order, payment, delivery, and guarantee.

The research data on Latvian cutomers' online shopping will be analyzed in the article. Consequently, the analysis of data will be carried 
out, based on 558 questionnaires obtained from respondents in Latvia.

According to the Central Statistical Bureau, the number of permanent residents of Latvia was 1968957 in 2016 [9]. Applying a simple random sampling method, it was calculated that the required number of respondents, in order to confirm the data obtained is reliable (with probability of 95\%) and represents the general sample, is 385 . Since, in fact, larger number of respondents (558) was surveyed, it can be stated that the data obtained with a probability of $95 \%$ demonstrates the customer behaviour doing online shopping [10].

All answers in the questionnaire were modelled according to a Likert scale. The range of the responses was the following: absolutely disagree; disagree; rather agree than disagree; agree; aboslutely agree.

The authors have applied SPSS software for data processing using descriptive statistics, means, frequencies.

Characteristics of the survey's participants. $25.8 \%$ of the respondents are 18-24 years old, $21.3 \%-25-34$, $38.9 \%-35-49,14.1 \%$ - 50 and more. $64.1 \%$ of the respondents have graduate (higher) education, $18.2 \%$ secondary education, $14.1 \%$ - vocational education, and $3.6 \%$ - primary education. In the research, a significant part of the respondents' characterization refers to the frequency of online shopping. $37.1 \%$ of the respondents do shopping few times per month, $31.5 \%$ - few times per year, $22.5 \%$ - less often, $8.5 \%$ - few times per week and $0.4 \%$ never.

\section{RESULTS AND DISCUSSION}

When researching the existing market or identifying a potential new market, marketing specialists have to put forward a number of questions and find answers that form a base of customer behaviour [1], [14] (Table 1).

Table I

Questions and objectives of the research of customer behaviour [1],

$$
\text { [14] }
$$

\begin{tabular}{|l|l|c|}
\hline \multicolumn{1}{|c|}{$\begin{array}{c}\text { Research } \\
\text { question }\end{array}$} & Research objective & Research example \\
\hline What is bought? & Purchase items & Products \\
\hline Why is it bought? & Purchase motif & $\begin{array}{c}\text { Description of a } \\
\text { product, price, } \\
\text { service }\end{array}$ \\
\hline Who buys? & $\begin{array}{c}\text { Characteristics of a } \\
\text { customer }\end{array}$ & $\begin{array}{c}\text { Roles in a purchasing } \\
\text { process }\end{array}$ \\
\hline How buys? & Purchasing actions & $\begin{array}{c}\text { Choice, selection, } \\
\text { decision-making }\end{array}$ \\
\hline When buys? & Purchasing time & $\begin{array}{c}\text { In a day, week, } \\
\text { season }\end{array}$ \\
\hline Where buys? & Purchasing place & $\begin{array}{c}\text { Traditional stores, } \\
\text { online shops, agents }\end{array}$ \\
\hline
\end{tabular}

In order to study the relationship between the market incentives and the responsiveness of customers, a model of customer action is designed. The model includes the following interrelated parts:
- External factors influencing customer behaviour (economic, political, technical, natural);

- Internal factors influencing customer behaviour (social, cultural, personal, psychological);

- Customer's decision-making process (emerging of needs, search for information, evaluation of alternatives, decision to buy, behaviour after the purchase);

- Customer's choice (product quality, product assortment, brand, price, place, and time of purchase, purchase form and payment) and decision [1].

The online retail sector is the main driver of growth in European retailing. While e-commerce growth rates hit $18.4 \%$ in 2014 and $18.6 \%$ in 2015 , growth is not expected to cease in the coming years with Retail Research predicting $16.7 \%$ growth in 2016 and $15.7 \%$ in 2017 [11], [12].

E-commerce is the fastest growing retail market segment in Europe, with growth expected to reach $£ 215.38$ bn [€250.28 bn] in 2017 (Centre for Retail Research). Shoppers and their habits are everevolving and it can be a daunting task for retailers to stay in front of expectations [3]. There is absolutely no doubt that Europe is a key market in terms of e-commerce. With significant year-onyear growth, yet much potential still to come, online retailers should not dismiss the opportunities Europe holds [12].

One of the most important indicators explaining frequency of shopping is the income level of the respondents (see Table 2). It can be stated that the increase of incomes leads to the increase of frequency of the respondents' online shopping.

Table II

Frequency of shopping according to the respondents' income level (by the authors, based on the survey data)

\begin{tabular}{|c|c|c|c|}
\hline \multirow[b]{2}{*}{$\begin{array}{l}\text { Often of shopping } \\
\text { online }\end{array}$} & \multicolumn{3}{|c|}{ Respondents' salary } \\
\hline & $\begin{array}{c}\text { Less or } \\
\text { minimum }\end{array}$ & $\begin{array}{c}\text { Between } \\
\text { minimum } \\
\text { and average }\end{array}$ & $\begin{array}{c}\text { Average or } \\
\text { more than } \\
\text { average }\end{array}$ \\
\hline Few times per week & 2.86 & 8.75 & 11.06 \\
\hline $\begin{array}{l}\text { Few times per } \\
\text { month }\end{array}$ & 42.86 & 34.17 & 37.98 \\
\hline Few times per year & 33.33 & 34.17 & 26.92 \\
\hline Less often & 20.00 & 22.50 & 24.04 \\
\hline Never & 0.95 & 0.41 & 0 \\
\hline Total & 100 & 100 & 100 \\
\hline
\end{tabular}

Four times more respondents with incomes "average or more than average" rather than those with incomes "less or minimum" do shopping online with frequecny "few times per week". 


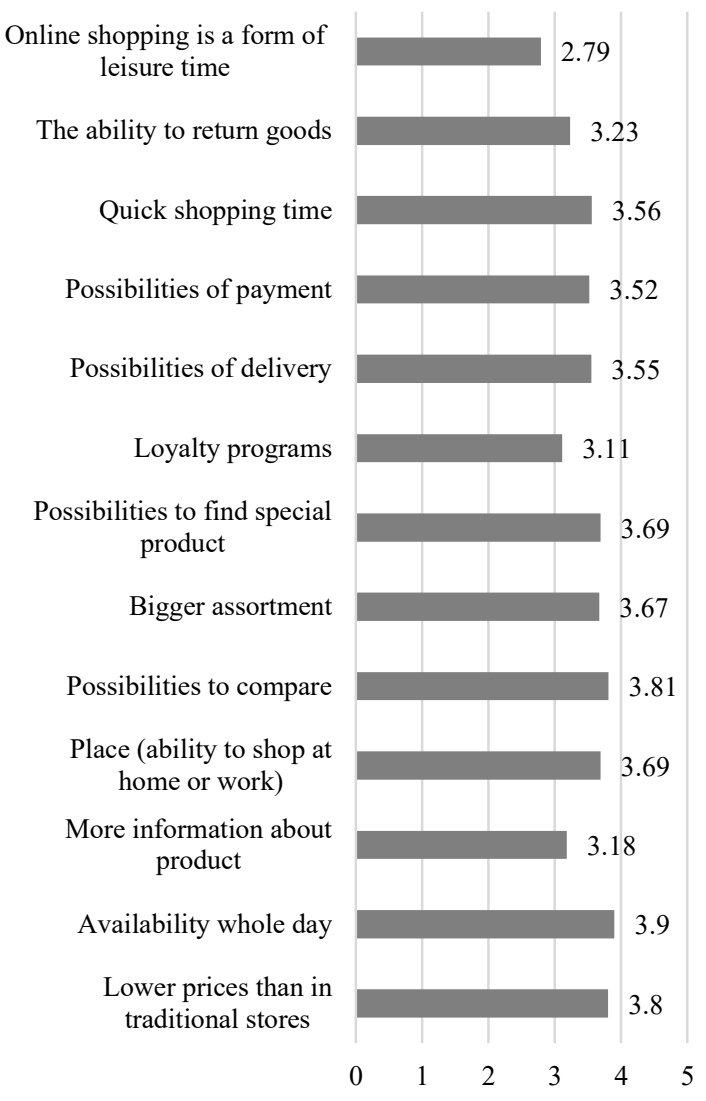

Fig.1. Respondents reasons for shopping online (by the authors, based on the survey data)

The respondents admit that availability whole day, lower prices than in traditional stores, and possibilities to compare are the main reasons for online shopping (Fig.1.). The respondents often do shopping in their free time that is probably even late at night or early in the morning. Price is one of the key indicators that determine customer behaviour and choice. In fact, the price comparison in traditional stores is time consuming and also money consuming process; and practically impossible for employed people. Accordingly, online shopping provides this opportunity. The least part of respondents perceive online shopping as a leisure activity. This means that online shopping has become an integral part of life for the satisfaction of needs. Hence, it is an opportunity for entrepreneurs to develop e-commerce.

The most online purchased items by the respondents are the clothes and tickets for leisure time (Fig.2.). Clothing has become the main product of online shopping due to availability to approach different manufacturers, providing choice by brand, price, and also taste.

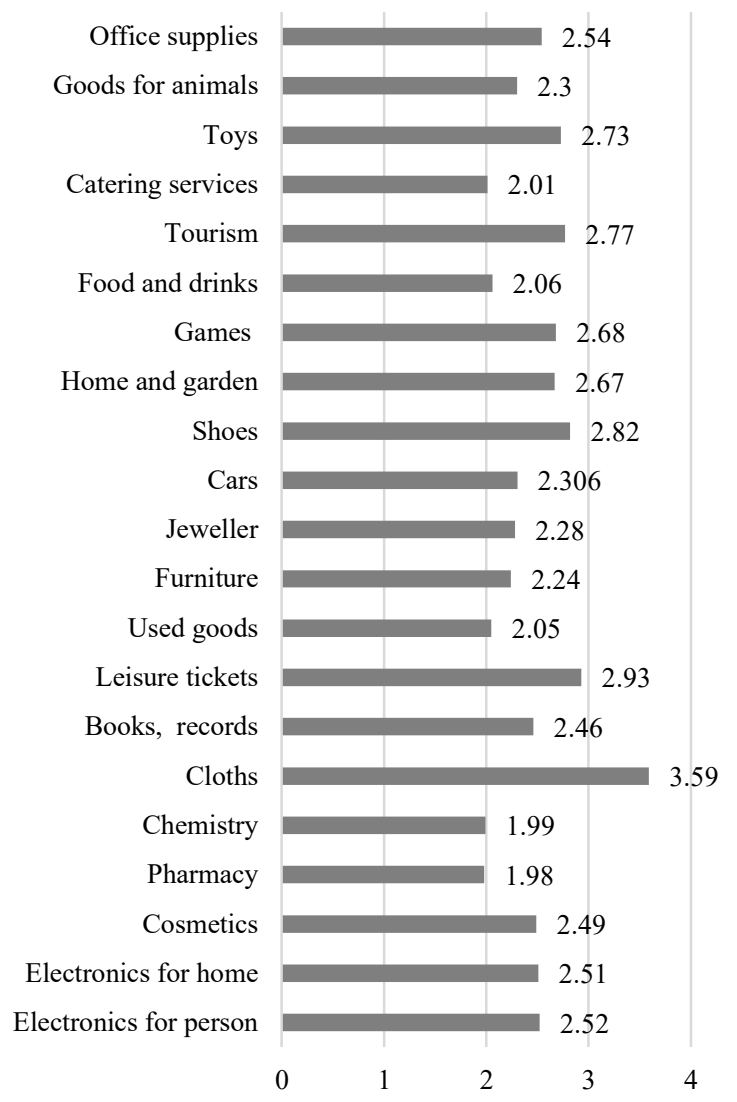

Fig.2. Goods most often bought by respondents (created by the authors, based on the survey data)

Event organizers mostly offer to purchase tickets using online services, for example, Bilešu paradīze. The purchases are easy to be carried out and userfriendly, as they do not require detailed analysis of product characteristics.

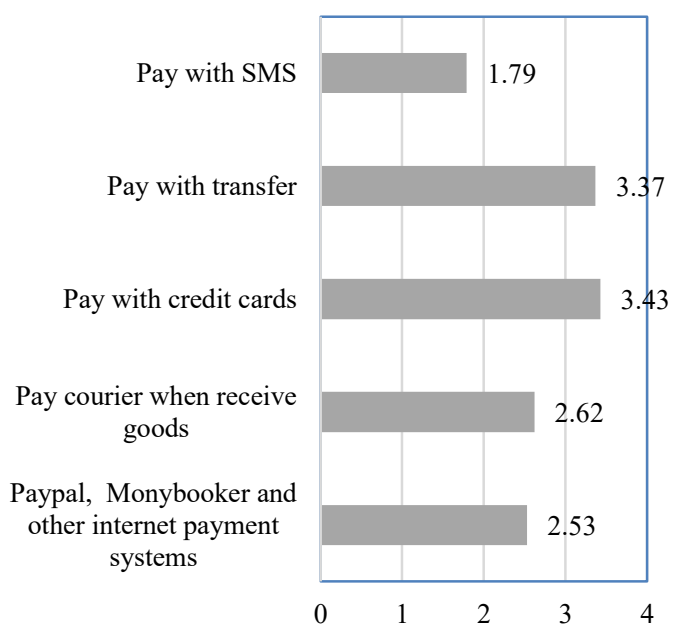

Fig.3. Payment methods used in online shopping (by the authors, based on the survey data)

The most popular forms of payment in online shopping are a transfer or payment by credit card (Fig.3.). These two are also the most common 
payment methods offered in e-environment. Fig.4. shows the reasons why these types of payment are so demanded.

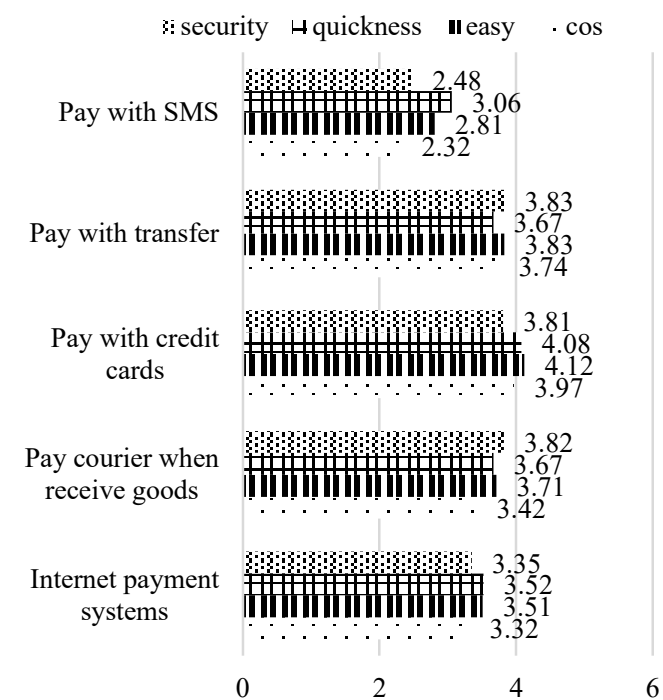

Fig.4. Assessment of the payment methods used in online shopping by cost, easiness, quickness, security (by the authors, based on the survey data)

Despite the fact that technologies are still developing, the respondents consider paying with transfer to be the most secure method of payment (Fig.4.) for purchases on the Internet (mean - 3.83) Payment with credit card is seen as the easiest method of payment by the respondents (mean-4.12). A relatively large number of respondents (mean - 3.83) consider payment with transfer as a simple method of payment. Payment with credit card has lower costs (mean - 3.97), and it is the fastest method of payment (mean - 4.08). The relatively low assessment by the respondents is provided for the payment with SMS. The authors believe, that is due to the relatively low popularity of this form of payment, preventing the possibility to fully assess it.

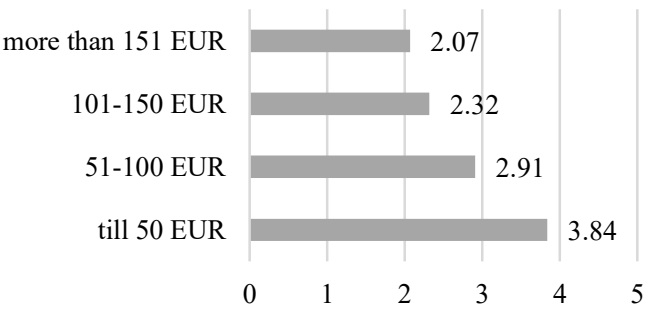

Fig.5. Money the respondents spend per one shopping session (by the authors, based on the survey data)

The respondents spend generally up to 50 EUR per one shopping session, since the income level of most of the respondents $(43.4 \%)$ is in the range from minimum to average (Fig.5.).

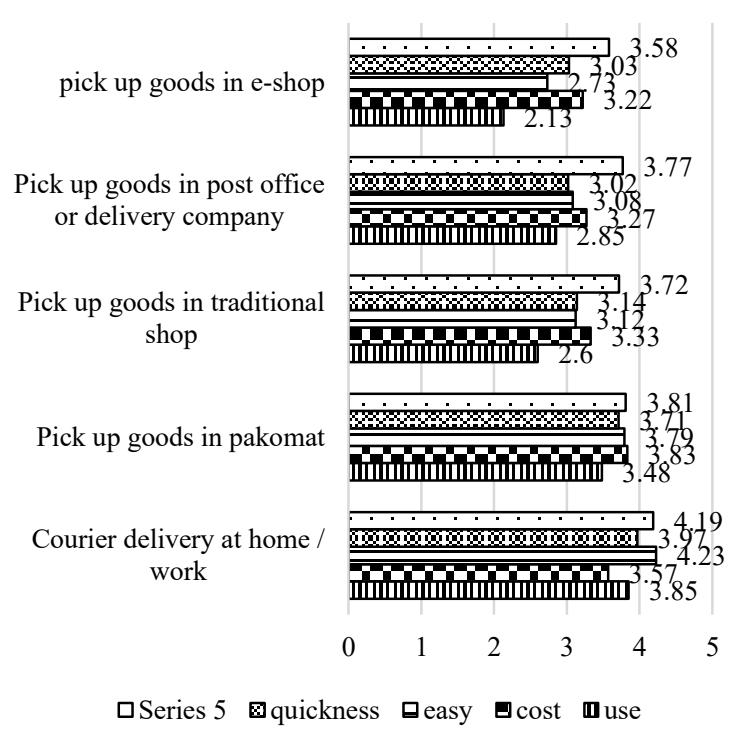

Fig.6. Assessment of types of delivery by frequency of use, cost, ease, quickness, security (by the authors, based on the survey data)

The most common type of delivery (Fig.6.) is the delivery of goods by courier to home or workplace (mean - 3.85). According to the respondents, this delivery method is the simplest (mean -4.23$)$, fastest (mean - 3.97), and also the most reliable (mean4.19).

The method of courier delivery at home/work indicates the customer's desire to save time and get the purchased goods in a place he/she finds comfortable. Pick up goods in pakomat gains a relatively high popularity. In Latvia, the pakomat are located in the parking lots of shopping centers providing a very convenient collection of goods. Going to a shopping center is also an opportunity to pick up goods ordered on the Internet. The respondents state it is one of the cheapest (mean - 3.83) delivery methods.

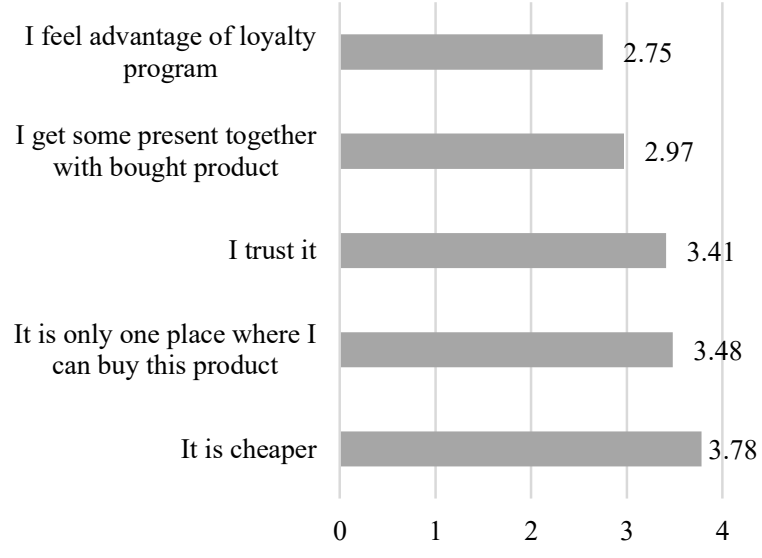

Fig.7. Reasons why respondents are ready to wait longer when doing online shopping (by the authors, based on the survey data)

Respondents state that the goods on the Internet are cheaper compared with traditional stores (Fig.1.), determining that they are willing to wait longer for 


\section{delivery (Fig.7.).}

Shopping online provides that money is paid at the beginning, goods are received only after some period of time, and a seller is unknown. This means that online shopping is associated with many risks (a product description or image in reality may be different, a seller could be fraudulent, etc.). Therefore, a customer needs guarantees in order to feel safe when doing shopping online.

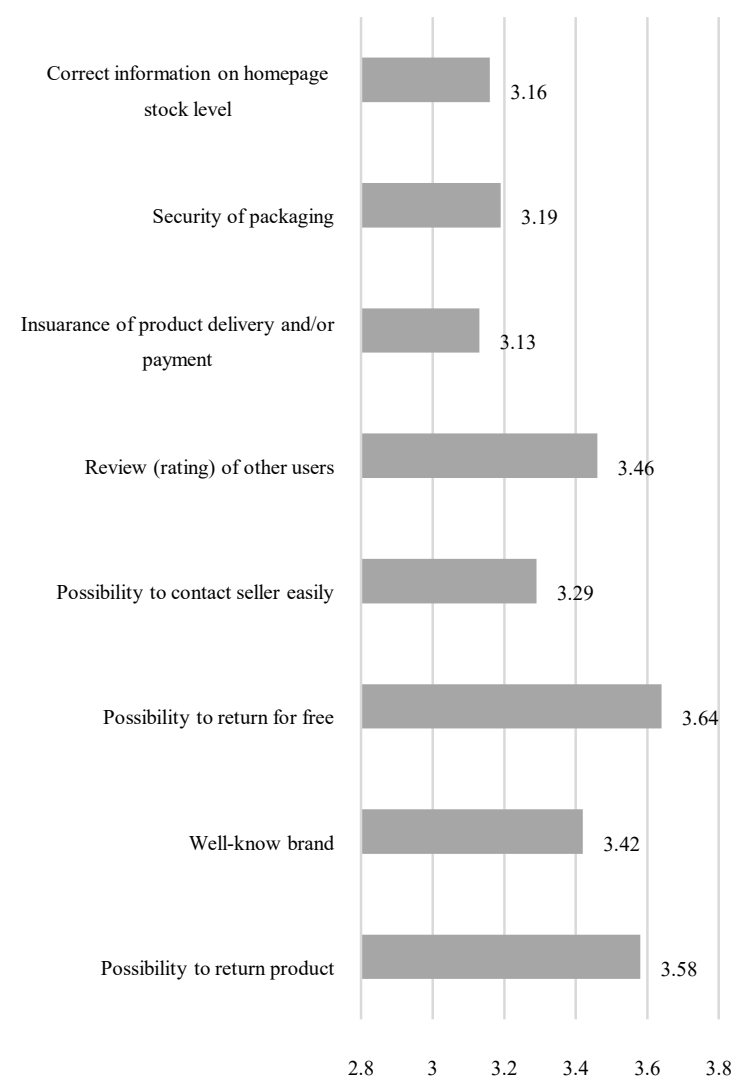

Fig.8. Guarantees the respondents pay attention to when doing shopping online (by the authors, based on the survey data)

One of the most important guarantees is the possibility of free return of goods (mean - 3.64), and the posibility of return (mean - 3:58) (Fig.8.). The respondents pay attention to the reviews (rating) of other users (mean - 3.46). This evidences that respondents are not certain about the ordered products and there is a probability that it will be necessary to return a product back to a seller, using the options prescribed by law.

However, it happens very often that an item is selected, but the order is not executed. There are several significant reasons for that (Fig.9.).

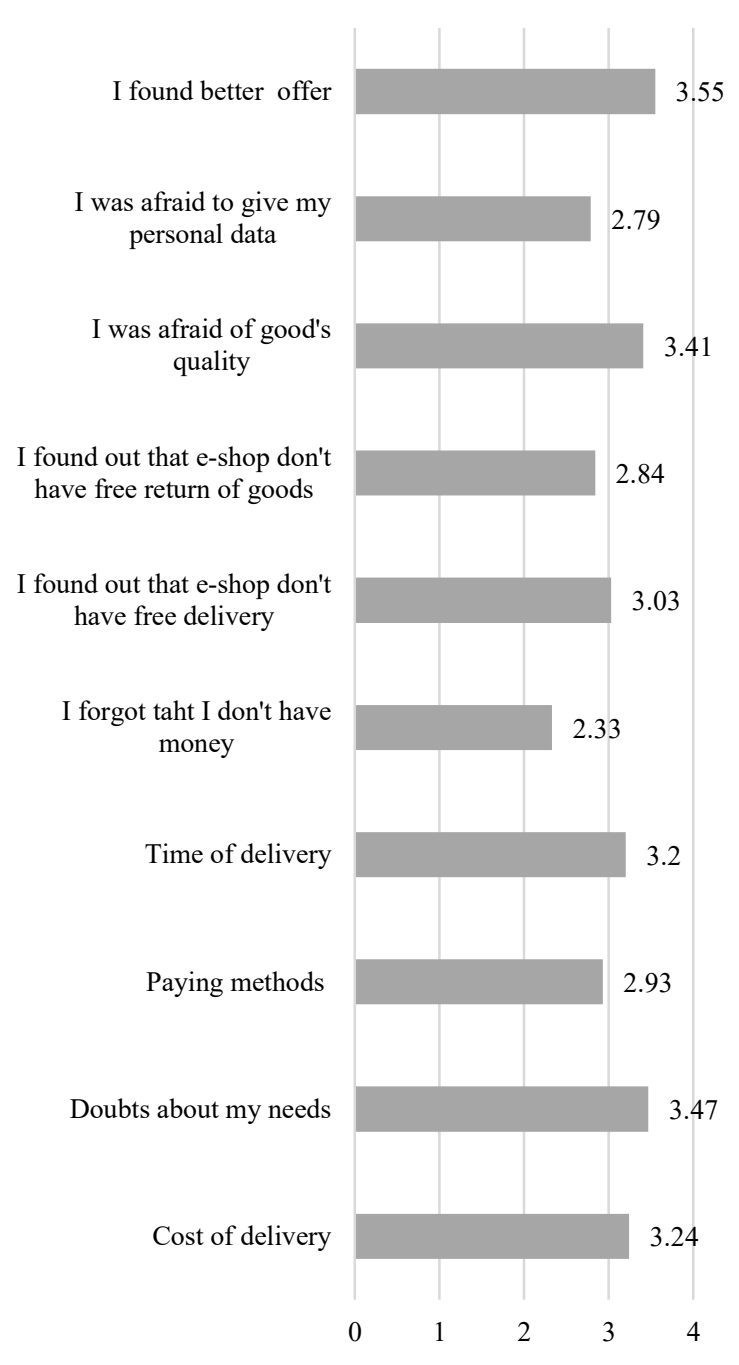

Fig.9. Problems the respondents face with when shopping online (by the authors, based on the survey data)

Most of the respondents do not complete the ongoing purchase (do not buy), because they find a better offer (mean - 3.55) (Fig.9.). Considerinng that the ability to do online shopping at any time is recognized as one of the advantages by the respondents, it also provides an opportunity to compare goods by criteria that are important to a customer (price, time and cost of delivery, quality, etc.).

\section{IV.CONCLUSIONS}

The frequency of online shopping and the amount of money spent is related with the income level of the customers. A higher level of income contributes to a higher frequency of online shopping and also increases the amount of money spent per one shopping session.

Customers are pretty conservative because most of then do online shopping just a couple of times per year.

Still the most popular are the traditional payment methods which are also perceived by clients as the 
most secure and convenient. The least popular are mobile payments.

Online shopping stores need to pay attention to delivery issues because the competitiveness among ecommerce companies increase.

Cost and quick delivery will be one of the main reasons for successful online business.

The best guarantee is good image and opinion about ebusiness.

\section{REFERENCES}

[1] V.Praude, Mārketings. 1.grāmata. teorija un prakse. Rīga, SIA „Burtene”, 2011. 528 lpp.

[2] I.Andresone and E.Gaile-Sarkane, Influence of factors on consumer behaviour. 5th International Scientific conference Business and management'2008, 16-17 May 2008, Vilnuius, Lithuania, pp. 331-337

[3] Report: Online shopping trends Europe, June 2016 [Online] Available:

https://blog.optimizely.com/2016/10/12/infographic-onlineshopping-trends-europe/ [Accessed: Jan.14, 2017]

[4] F.R.Kardes, Consumer behaviour and managerail decison making. Pearson Prentice-Hall, 2002, 457 p.

[5] S.Jang, A.Prasad and B.T.Ratchford, How consumers use product reviews in the purchase decision process. Marketing Letters, 2012. 23 (3), p. 825-838

[6] D.N.B. Gajjar. "Factors Affecting consumer behaviour". International Journal of research in Humanities and social science, 2013. 1(2)
[7] G.H.Gessner and C.R.Snodgrass, Designing e-commerce cross-border distribution network for small and medium-size enterprises incorporating Canadian and U.S. trade incentive programs. Research \& Management 16 (2015), p. 84-94

[8] M.Kadłubek, "The selected areas of E-logistics in Polish Ecommerce. International Conference on Communicaton", Management and Information Technology. Procedia Computer Scienece 65 (2015) p. 1059-1065

[9] Centrālā Statistikas pārvalde. [Online]. Available: http://data.csb.gov.lv/pxweb/lv/Sociala/Sociala ikgad iedz iedzskaits/IS0010.px/table/tableViewLayout2/?rxid=09 $\mathrm{cbd}$ ccf-2334-4466-bdf7-0051bad1decd [Accessed: 13.12.2016].

[10] Raosoft Inc. (2004). [Online] Available: http://www.raosoft.com/samplesize.html [Accessed: 12.03.2016].

[11] Online Retailing: Britain, Europe, US and Canada 2016 [Online] Available: http://www.retailresearch.org/onlineretailing.php [Accessed: 19.12.2016].

[12] E-commerce in Europe 2016: Facts \& Figures [Online] Available: https://www.twenga-solutions.com/en/insights/ecommerce-europe-2016-facts-figures/ [Accessed: 19.12.2016].

[13] Discover the results of our survey: Customer acquisition a key issue for online retailers in 2016 [Online] Available: https://www.twenga-solutions.com/en/insights/retailersurvey-2016-customer-acquisition-e-commerce/ [Accessed: 19.12.2016].

[14] M.Khaniwale, "Consumer Buying Behaviour". International Journal of Innovation and Scientific Research. Vol. 14 No. 2 Apr.2015, pp.278-286, ISSN 2351-8014 